University of Louisville

ThinkIR: The University of Louisville's Institutional Repository

Faculty Scholarship

$6-2008$

\title{
Gender, race, and intersectionality on the federal appellate bench.
}

Todd Collins

Laura Moyer

University of Louisville, laura.moyer@louisville.edu

Follow this and additional works at: https://ir.library.louisville.edu/faculty

Part of the American Politics Commons, Courts Commons, Gender and Sexuality Commons, Judges Commons, and the Race and Ethnicity Commons

\section{Original Publication Information}

This is the peer reviewed version of the following article:

Collins, Todd and Laura Moyer. "Gender, Race, and Intersectionality on the Federal Appellate Bench." 2008. Political Research Quarterly 61(2): 219-227.

which has been published in final form at http://dx.doi.org/10.1177/1065912907306467.

This Article is brought to you for free and open access by ThinkIR: The University of Louisville's Institutional Repository. It has been accepted for inclusion in Faculty Scholarship by an authorized administrator of ThinkIR: The University of Louisville's Institutional Repository. For more information, please contact thinkir@louisville.edu. 


\author{
Todd Collins \\ Western Carolina University, Cullowhee, North Carolina \\ Laura Moyer \\ University of Georgia, Athens
}

\begin{abstract}
While theoretical justifications predict that a judge's gender and race may influence judicial decisions, empirical support for these arguments has been mixed. However, recent increases in judicial diversity necessitate a reexamination of these earlier studies. Rather than examining individual judges on a single characteristic, such as gender or race alone, this research note argues that the intersection of individual characteristics may provide an alternative approach for evaluating the effects of diversity on the federal appellate bench. The results of cohort models examining the joint effects of race and gender suggest that minority female judges are more likely to support criminal defendants' claims when compared to their colleagues on the bench, even after controlling for other important factors. This suggests that our understanding of judicial behaviors may be assisted by the inclusion of how individual characteristics overlap rather than examining those characteristics alone.
\end{abstract}

Keywords: judges; gender; race; intersectionality; U.S. courts of appeals; judicial behavior; criminal law

Black women are silenced between the rocks and the hard places of racism and sexism. One way of beginning to think about this space is suggested by the concept of intersectionality. . . . This dual vulnerability [of African-American women] does not simply mean that our burdens are doubled, but instead, that the dynamics of racism and sexism intersect in our lives to create experiences that are sometimes unique to us.

\section{- Crenshaw (1992, 1467-68)}

Female members of a racial minority occupy a unique place within society. As this quote from Kimberle Crenshaw (1992) suggests, female minorities endure experiences and face challenges distinctive from Caucasian females or minority males. ${ }^{1}$ Since the 1970s, the number of female and minority judges has continued to increase in the federal judiciary. However, though a great deal of work has explored the nature of judicial decision making in the federal courts, there is little evidence to suggest that the recent diversification of the federal bench has yielded any substantive impact in the kinds of decisions rendered. The reason for these "mixed" findings concerning race and gender is that judges, as with other political elites, are not simply influenced by one individual characteristic but by a host of personal traits that collectively impact their behaviors.
As Crenshaw suggested, being a member of a minority group and being a female, or the intersectionality of gender and race, will create unique experiences for female minority judges and may lead to unique behaviors in judicial decision making. Using an integrated model, this research note examines the question of whether this intersectionality influences judicial decisions, as opposed to racial or gender status alone.

\section{Assessing Behavioral Differences Based on Group Membership}

There are two general theoretical perspectives that seek to explain how social attributes might work to influence individuals' behavior. The socialization model emphasizes the way in which judges, like other individuals, acquire their political orientations through a developmental process of socialization (Easton and Dennis 1969). Similar to the theoretical underpinnings of symbolic politics research, the model assumes that cases (as "symbols") trigger predispositions that lead to political behavior (Schubert 1965). A second theoretical linkage suggests attributes are indicators of influences on behavior that are not connected to a developmental process of socialization. Under this approach, a trait may be related to behavior because it is linked to self-interest or 
identification with a reference group. For example, substantive representation theory argues that when circumstances and discretion allow, public officials will act to benefit members of groups of which they are a part (e.g., Keiser et al. 2002). While it is beyond the scope of this article to empirically differentiate between these two broad themes, these theories have lead to more specific approaches to examining behavioral differences between group members. Scholarship from various fields has also specifically examined the relationship between gender and behavior as well as race and behavior. Concerning gender, Gilligan (1982) suggested that differences stemming from role orientations developed during childhood may lead females to arrive at different conclusions than males. Others posit that substantial behavioral differences may result from the historical limitations, both legal and cultural, placed on females (Schlozman, Burns, and Verba 1994). Building on these theoretical groundings, scholars have noted differences in behaviors based on gender in areas such as voting behavior (Norrander 2003), running for political office (Schlozman, Burns, and Verba 1994), and serving in legislative bodies (Dolan and Ford 1995; Swers 2002).

By and large, research examining judicial decision making has not found broad-based support for the proposition that a judge's gender influences the decisions rendered. Several studies have found some consistent gender-based differences in employment discrimination cases, with women judges being more likely than their male colleagues to support the position of the plaintiff (Peresie 2005; Songer, Davis, and Haire 1994). Male and female judges have also been found to differ with respect to sentencing decisions (Gruhl, Spohn, and Welch 1981). Allen and Wall (1993) found that women were more supportive of the profemale position and exhibited more extreme voting behavior than male judges. However, Segal's (2000) examination of President Clinton's district court judges found that female judges were no more likely to support women's issues than male judges. In the federal appellate courts, Davis's (1991) matchedpairs analysis failed to uncover significant differences between male and female judges, consistent with Songer, Davis, and Haire (1994), who found no significant effects for gender outside of the employment discrimination context. In sum, empirical findings suggest that a judge's gender may matter in decision making only in limited circumstances.

Like gender, an individual's race may shape personal identity, interactions with others, availability of life chances, and perceptions about availability of those chances (Prestage 1991). Opinions about crime are one area where researchers have found significant differences between individuals of different races. African Americans have been disproportionately impacted by more stringent crime control policies (Kennedy 1997), are more likely than Caucasians to have a liberal disposition toward criminal issues (Browning and Cao 1992) and civil liberties issues (Pierce, Beatty, and Hagner 1982), are more likely to lack confidence in the police (Cao and Franks 1996), and are more afraid that the police will arrest them if they are innocent (National Center for State Courts 1999). Based on data from the 1995 National Opinion Survey on Crime and Justice, African American and Hispanic respondents are more likely than white respondents to express dissatisfaction with the criminal court system (Myer 1996). African Americans are also significantly more likely to perceive bias and discrimination in the criminal justice system than white Americans, even after controlling for income, education, age, and class (Hagan and Albonetti 1982). A recent survey also found that more than 30 percent of African American respondents and 27 percent of Hispanic respondents said that treatment of African Americans was "far worse" than other groups, compared to only 9 percent of Caucasians that shared that belief (National Center for State Courts 1999). Studies of political elites also suggest that race impacts legislative agenda setting and policy making at the state level (Bratton and Haynie 1999; Miller 1990).

Concerning judges, disparities have been found with respect to trial court sentencing and a judge's race (Welch, Combs, and Gruhl 1998). President Carter's African American male circuit court appointees were found to be more likely to support liberal outcomes than their white male counterparts in criminal appeals (Gottschall 1983). Other findings suggest that racial minority judges on the U.S. courts of appeals are more likely to dissent than nonminority judges (Hettinger, Lindquist, and Martinek 2004). Another recent analysis found that substantive representation with respect to race may occur with African American judges in search and seizure cases (Scherer 2004-2005). This behavior reflected differences between African American and Caucasian respondents in public opinion polls on police misconduct, suggesting that African American judges provide substantive representation for African American citizens on this issue. However, other studies, such as Walker and Barrow's (1985) federal district court analysis, find no significant effects for race on judicial outcomes. 


\section{The Intersection of Gender and Race in Judging}

It is, however, important to remember that group membership overlaps between gender and racial categories. As Kane $(1992,311)$ wrote, "The intersection of racial and gender inequalities creates unique structural positions for black women, black men, white women, and white men." The work of Hancock (2007) and Crenshaw (1989, 1992) focused specifically on the "intersectionality" of women of color and how their experiences have been marginalized by both antiracist groups and feminist groups, each of which argue that disadvantage occurs along a single, categorical axis (i.e., race or gender, but not both). African American women, Crenshaw (1989, 149) argued, "can experience discrimination in ways both similar to and different from those experienced by white women and black men."

Along these same lines, Angela Harris (1990, 58788) argued that current feminist theory ignores the "multi-vocal" facets of women's experiences, including differences in race, social class, and sexual orientation, and instead bases its understanding of the category "woman" only on the experiences of white women. Given these critiques, it is important to take into account the unique experience of being both female and a member of a racial minority when attempting to discern the impact of demographic factors on judicial behavior.

Little empirical research has examined these crossroads, although some prior studies have found unique effects for gender and race. In their experimental study about perceptions of justice, Miller, Rossi, and Simpson (1986) found evidence that the intersection between race and gender influences individual views on appropriate punishment for crimes. White men and white women seem to adopt a perspective that focuses on the proportionality of punishment to the crime committed, regardless of the offender; in contrast, African Americans, particularly African American women, appear to be more greatly influenced by offender characteristics, sentence duration, and mitigating circumstances than by crime seriousness (p. 332). While black females supported harsher punishments than males or white females for some types of crimes, for other violent crimes such as intentional shootings, rape, and setting a bomb, black females supported less harsh punishments than whites or African American males (pp. 327-28). These findings suggest the existence of structurally based differences in judgments about justice that seem to vary by race and gender. Another study, based on interviews of 106 police officers, found perceived differences based on race, gender, and the intersection of these two characteristics (Martin 1994). This qualitative study found that African American women felt they were victims of racial and sexual discrimination more than white females or African American males. African American female officers' experiences and beliefs also affected how they conducted their jobs, more so than white women or minority-male officers:

Black women face uncertainties related to both co-worker backup and to unpredictable responses of citizens to black women exercising authority. They also are aware of the historical role of police as oppressors in the black community. These factors contribute to their reluctance to adopt the policing style characteristic of white men who are enthusiastic about "aggressive patrol" and seeking out crime and criminals. (Martin 1994, 391)

Building from the theoretical contributions of Crenshaw $(1989,1992)$ and the experimental work of Miller, Rossi, and Simpson (1986), our research empirically tests whether the group membership of federal appellate court judges has a discernable affect on their voting behavior. Given the prior studies and theories on the influence of individual characteristics on behavior, we expect that female-minority judges will have unique voting behaviors as compared to the voting behavior of Caucasian men, minority men, and Caucasian women. Specifically, we expect the female-minority judges, being members of two "outgroups," will support more liberal outcomes than whites or minority females. However, to ensure that intersectionality is indeed influential, we will also need to test for the effects of race or gender alone.

\section{Data and Measures}

To test the influence of intersectionality, we draw our cases from the Multi-User Database on the U.S. Courts of Appeals supplemented by the update extending the sample. ${ }^{2}$ In our analysis, we utilize only criminal cases decided between 1977 and 2001, as 1977 marks a time of increased diversity on the federal bench compared to previous decades (Goldman 1997). We also relied upon the Zuk, Barrow, and Gryski (1997) Database on the Attributes of U.S. Appeals Court Judges ${ }^{3}$ and the Federal Judicial Center (see History of the Federal 
Judiciary, www.fjc.gov) to supply information on judge characteristics. Each case was weighted to represent a random sample (Songer 1997). The unit of analysis is a judge's vote in a given case, which yields 6,219 total observations, including 348 different judges. ${ }^{4}$

Our sample includes only criminal cases for several reasons. First, earlier studies have found race- and gender-based differences in public opinion on criminal justice (Curran 1977; Miller, Rossi, and Simpson 1986) and in judges presiding over criminal appeals (Scherer 2004-2005). Second, criminal cases make up a large proportion of the circuit court docket, which increases the generalizability of our findings as well as the number of observations for the analysis. Finally, judges exhibit a greater degree of ideological consistency in this issue area than other areas, because criminal cases fall along a single ideological dimension. It may be argued that, even within the criminal context, case characteristics vary such that only certain specific issues in the criminal context should be examined (e.g., Scherer 2004-2005; Segal 1986). Our study, however, uses all criminal cases to provide more generalizable interpretations of judicial decision making. While the specific legal issues may differ within these cases, the underlying principles generally remain the same: balancing the interests of due process versus the importance of protecting society from criminal activities. A "law and order" judge should be more likely to support the prosecution whether the issue is improper admission of any type of evidence, improper jury instructions, or prosecutorial misconduct. Similarly, a judge suspicious of the criminal justice system and protective of due process may be more likely to support the defendant in a wide range of criminal issues. For this reason, a broader range of legal issues was selected, still within the criminal context, to find overall trends based on racial and gender characteristics as well as the joint membership in possible out-groups.

The dependent variable, judicial voting in criminal cases, is coded as "liberal" (prodefendant) or "conservative" (proprosecution). Our main independent variables of interest are the judge's race, gender, and the intersection of these two variables. To test for the influence of gender or race alone, we created dummy variables based on race and gender and conducted models with these and other control variables. To test the combined effect of being both female and a member of a minority group, we conducted a cohort analysis, ${ }^{5}$ defining the cohorts by race and gender: Caucasian males, Caucasian females, minority males, and minority females (the excluded, reference category).

One limitation in examining intersectionality involves the small number of minority female judges serving on the federal courts of appeals. While the federal bench has become more diversified, particularly under the Carter and Clinton administrations (Goldman 1997), only six female minority judges served during the period included in the study, 1977 to 2001. These female-minority judges included four African American females and two Hispanic females (Federal Judicial Center n.d.). Although this small number may somewhat limit the generalizablity of any results, the six minority-female judges do represent the entire universe for this period. Furthermore, any results that are found concerning the intersectionality of race and gender would be more noteworthy given the small sample. As has been noted, "A factor that is large enough to produce differences that are statistically significant in a small sample is . . . much more worthy of one's attention that a factor that produces small differences that can only be shown to be statistically significant within a very large sample" (Blalock 1979, 163).

To assess the role of race and gender properly, our model also includes several controls. Judicial ideology can be a powerful predictor of voting behavior, even on the courts of appeals (Songer and Davis 1990; Songer and Haire 1992). We use Giles, Hettinger, and Peppers (2001) scores as a proxy for judge policy preferences. We have multiplied these scores by -1 so that they range from -1 (most conservative) to 1 (most liberal). Likewise, studies have noted that judges born in the South may be more conservative than their counterparts born in other regions even after controlling for other factors such as the nominating president (Songer and Davis 1990). Therefore, a dummy variable will be included to control for this regional effect. We also controlled for the age of the judge, as age has been linked to judges' ideological predispositions in certain case types and in public attitudes toward law and order (Manning, Carroll, and Carp 2004).

Institutional norms of consensus in the circuit courts may promote accommodation among panel members, as is evidenced by the influence of a panel's ideological composition on individual judges' decisions (Hettinger, Lindquist, and Martinek 2004, 2006; Cross and Tiller 1998; Songer 1982). To control for this group dynamic, the median Giles, Hettinger, and Peppers (2001) score is included as a measure of the panel's ideological predisposition. Given the potential for rehearing en banc and the possibility of socialization from other members of the bench, the model also includes a variable that represents the ideology score for the median judge in the circuit for the year in which the case was decided. All 
of these ideology measures should be positively related to a liberal vote. To account for differences between the circuits that may not be captured by these controls, we include dummy variables for all circuits, with the D.C. Circuit as the excluded category.

Because of the mandatory dockets, many circuit court cases are routine, where the law and the facts are clear and judges have little decision-making discretion. To account for the tendency, we control for the circuit court's predisposition to affirm the decision below by including a variable for the trial court's decision. This variable was coded 1 if the lower court decided in a liberal direction and 0 if it was in a conservative direction. As the U.S. government may have advantages in the resources available to prosecute its cases (Songer and Sheehan 1992), we also control for the federal government's advantages by including a variable coded 1 if the U.S. argues the liberal position, -1 if conservative, and 0 if the position was unclear or if the U.S. government was not a party in the case. This variable is predicted to be positive in that the circuit court judges are more likely to rule for the liberal position if the federal government takes that position. The court of appeals' position as an intermediary court also suggests that it may be responsive to higher authorities (Songer, Segal, and Cameron 1994). Therefore, the model includes a control for the percentage of liberally decided Supreme Court cases dealing with social issues, such as cases involving criminal rights and procedures, civil rights and liberties, privacy, among others (Segal, Timpone, and Howard 2000), lagged by one year.

Finally, certain issues may become more salient over time, possibly due to recent presidential administrations' emphases on certain policies and platforms. For example, through the "War on Drugs," Presidents Reagan and G. H. W. Bush promoted a tougher position on crime, including higher penalties for criminal activities and an increased pressure on all government officials to get tough on crime (Whitford and Yates 2003). To control for broad differences in policy and the political environment associated with presidential administrations, time period controls were included.

\section{Results}

Looking merely at the votes themselves, the trends appear to support the expectations (see Table 1). As expected from prior studies, minority male judges and minority female judges supported the defendants' position more often than their Caucasian peers
Table 1

Voting by Judge Race and Gender: Criminal Cases before the U.S. Courts of Appeals (1977-2001)

\begin{tabular}{lccc}
\hline $\begin{array}{l}\text { Race and Gender } \\
\text { Cohort (Number } \\
\text { of Judges) }\end{array}$ & $\begin{array}{c}\text { Percentage of Percentage } \\
\text { Conservative } \\
\text { Votes }\end{array}$ & $\begin{array}{c}\text { Percentage of } \\
\text { Liberal } \\
\text { the Total Votes } \\
\text { in Sample }\end{array}$ \\
\hline Caucasian males (273) & 80.0 & 20.0 & 84.1 \\
Caucasian females (38) & 77.0 & 23.0 & 7.6 \\
Minority males (31) & 75.3 & 24.7 & 7.3 \\
Minority females (6) & 66.1 & 33.9 & 1 \\
All (348) & 79.3 & 20.7 & 100 \\
\hline
\end{tabular}

did. Minority women, being members of two outgroups, cast the highest percentage of liberal votes (33.9 percent), suggesting that dual membership in the out-groups of race and gender produces distinctive behavior among that cohort.

However, to better assess the influence of race and gender, a more refined analysis is needed. Since the dependent variable is dichotomous, we utilize binary logistic regression models (Liao 1994), clustering on each judge to produce robust standard errors (Long and Freese 2003, 74). To more rigorously test for unique voting behaviors based on race and gender, we conducted a logit analysis including a dummy variable for the race of the judge and then a second logit with a variable for gender.

Unlike the descriptive findings, however, those judges belonging to a racial minority were statistically no more likely to support the defendant's position than nonminorities. As the second column in Table 2 displays, the lack of statistical significance for the race variable generally supports examinations from other scholars that find few racial differences in judicial voting. While other factors, such as the judge's ideology and case-based factors such as the panel ideology and the lower court's decision influence judicial voting, distinctions in judicial voting cannot be made from examining the judge's race alone.

To examine the possibility of unique voting patterns for women judges, we conducted a similar model by including a variable for the judge's gender. As with the racial variable in the previous model, the third column of Table 2 indicates that no statistically significant differences appear between male and female judges. While other variables again appear important, the gender of the decision maker does not appear to be an influential factor in judicial voting in criminal cases. While it is difficult to prove a negative through the null findings for race and gender in Tables 2, these 
Table 2

Racial and Gender DifferencesLogit Model: Likelihood of a Liberal Vote in Criminal Cases, U.S. Courts of Appeals, 1977-2001

\begin{tabular}{|c|c|c|}
\hline Variable & $\begin{array}{c}\text { Racial Differences } \\
\text { in Judicial Voting: } \\
\text { Coefficient } \\
\text { (Robust Standard } \\
\text { Error) }\end{array}$ & $\begin{array}{c}\text { Gender Differences } \\
\text { in Judicial Voting: } \\
\text { Coefficient } \\
\text { (Robust Standard } \\
\text { Error) }\end{array}$ \\
\hline \multicolumn{3}{|l|}{ Individual judge controls } \\
\hline Race & $-.112(.164)$ & - \\
\hline Gender & - & $-.010(.100)$ \\
\hline Judge's ideology & $.416^{* * *}(.127)$ & $.394 * *(.128)$ \\
\hline South & $-.287 *(.121)$ & $-.281 *(.120)$ \\
\hline Judge's age during case & $-.005(.004)$ & $-.055(.004)$ \\
\hline \multicolumn{3}{|l|}{ Case-specific controls } \\
\hline Panel median ideology & $.876^{* * *}(.168)$ & $.874 * * *(.168)$ \\
\hline Circuit ideology median & $.065(.204)$ & $.069(.204)$ \\
\hline Lower court decision & $.734 * * *(.096)$ & $.732 * * *(.097)$ \\
\hline U.S. government position & $.441 * * *(.075)$ & $.440 * * *(.075)$ \\
\hline Supreme Court liberalism & $-.006(007)$ & $-.006(.007)$ \\
\hline \multicolumn{3}{|l|}{ Year and circuit controls $\mathrm{s}^{\mathrm{a}}$} \\
\hline $1977-1981$ & $.429 * * *(.107)$ & $.432 * * *(.107)$ \\
\hline 1994-2001 & $.195 *(.088)$ & $.191 *(.090)$ \\
\hline First Circuit & $-.848 * * *(.210)$ & $-.835(.203)$ \\
\hline Seventh Circuit & $-.945^{* * *}(.182)$ & $-.953 * * *(.178)$ \\
\hline Eighth Circuit & $-.847 * * *(.192)$ & $-.838(.189)$ \\
\hline Constant & $-.548(.323)$ & $-.576(.326)$ \\
\hline Wald chi-square & 388.59 & 386.85 \\
\hline Prob $>$ chi-square & .000 & .000 \\
\hline Pseudo- $R^{2}$ & .068 & .068 \\
\hline$N$ & 6,219 & 6,219 \\
\hline
\end{tabular}

a. Due to space limitations, only those circuit dummy variables with statistically significant coefficients are reported.

$* p \leq .05 . * * p \leq .01 . * * * p \leq .001$.

results give a strong indication that gender and racial differences alone do not produce significant differences in the decision making of the appellate judges. ${ }^{6}$

Still left unexplored, however, is the question of joint membership in these groups, or the intersection of race and gender. Table 3 displays the result of a cohort analysis, utilizing the minority female cohort as the base term. Since their membership in two out-groups and the descriptive statistics suggest that female minority judges are more likely to cast prodefendant votes than white males, white females, or minority males, then we should expect that the coefficients for all other cohort variables will be negative in the model.

As expected, the results in Table 3 indicate that each cohort is more likely to support a conservative position when compared to votes cast by minority-female judges. The sign of the estimated coefficient for each cohort variable is negative, and the relationships are statistically significant, even after controlling for other factors such as individual judge ideology, panel ideology, and the lower court decision. While the earlier results
Table 3

Logistic Regression Estimates: Likelihood of a Liberal Vote in Criminal Cases, U.S. Courts of Appeals, 1977-2001

\begin{tabular}{|c|c|}
\hline Variable & $\begin{array}{c}\text { Coefficient (Robust } \\
\text { Standard Error) }\end{array}$ \\
\hline \multicolumn{2}{|l|}{ Racial cohorts } \\
\hline Caucasian-male judge & $-.399 *(.171)$ \\
\hline Caucasian-female judge & $-.499 * *(.175)$ \\
\hline Minority-male judge & $-.596 * *(.231)$ \\
\hline \multicolumn{2}{|l|}{ Other individual controls } \\
\hline Judge's ideology & $.420 * * *(.121)$ \\
\hline South & $-.295 *(.122)$ \\
\hline Judge's age during the case & $-.005(.004)$ \\
\hline \multicolumn{2}{|l|}{ Case and circuit controls } \\
\hline Panel median ideology & $.877 * * *(.168)$ \\
\hline Circuit ideology median & $.076(.205)$ \\
\hline Lower court decision & $.735 * * *(.097)$ \\
\hline U.S. government position & $.442 * * *(.075)$ \\
\hline Supreme Court liberalism & $-.007(.007)$ \\
\hline \multicolumn{2}{|l|}{ Year and circuit controls ${ }^{\mathrm{a}}$} \\
\hline $1977-1981$ & $.424 * * *(.107)$ \\
\hline 1994-2001 & $.197(.090)$ \\
\hline First Circuit & $-.843 * * *(.204)$ \\
\hline Fourth Circuit & $.344 *(.174)$ \\
\hline Seventh Circuit & $-.978 * * *(.177)$ \\
\hline Eighth Circuit & $-.838 * * *(.189)$ \\
\hline Constant & $-.133(.340)$ \\
\hline Wald chi-square & 416.26 \\
\hline Prob $>$ chi-square & .000 \\
\hline Pseudo- $R^{2}$ & .068 \\
\hline$N$ & 6,219 \\
\hline
\end{tabular}

a. Due to space limitations, only those circuit dummy variables with statistically significant coefficients are reported. $* p \leq .05 . * * p \leq .01 . * * * p \leq .001$.

did not support the proposition that behaviors differences exist based on gender or race, alone, the analysis supports the position that being female and a racial minority influences judicial decision making.

Examining the predicted probabilities (not shown) provides another means by which we may explore the differences in judicial voting. Holding all other variables at their means, the model predicts that minorityfemale judges will support the criminal defendant's position in 25.91 percent of the cases. White-male judge were predicted to support a liberal outcome in 19.01 percent of their cases, white-female judges in 17.52 percent, and minority-male judges in 16.15 percent. All predicted probabilities were statistically significant at a 95 percent confidence interval. Thus, female-minority judges were approximately between 6 to 10 percent more likely to support a liberal outcome than males or Caucasian females. While the other cohorts are statistically indistinguishable from 
each other, a unique pattern of judicial decision making emerges concerning female minority judges. ${ }^{7}$

\section{Conclusions}

When examining race and gender in isolation, this study joins others in finding no results. However, unlike earlier studies of federal court diversification, we do find that there are significant differences in the voting behavior of minority female judges. They are significantly more likely than minority males, Caucasian females, and Caucasian males to support criminal defendants' claims, even after controlling for ideology and other important factors. This finding lends credence to arguments made by Crenshaw $(1989,1992)$ and others that minority women may have a distinctive identity that differs significantly from Caucasian women and minority males. While surveys and studies show race and genderbased differences of opinion on criminal matters, female minorities may share common opinions that are even stronger than the subgroups to which they belong. These common opinions may be the result of shared socialization or, alternatively, the result of a conscious decision to provide substantive representation for the group with whom these judges most closely identify. Although it is beyond the scope of this analysis to distinguish between these two explanations here, future research on intersectionality may shed more light on whether one or the other of these explanations may further clarify these unique voting patterns.

Clearly, there are limitations to this study. The sample includes a small number of minority female judges, all of whom were appointed by either President Carter or President Clinton, and these limitations affect the generalizability of our results. However, unlike past research, this study found clear differences among this small group as compared to their counterparts. ${ }^{8}$ The fact that statistically significant findings were achieved despite the small $N$ may provide credence to the prospect that this is indeed a unique voting group of judges. Rather than undermine the current results, we argue this necessitates the importance of further attention to the theory underlying these characteristic crossroads. For example, as of fall 2006, President George W. Bush had appointed three minority female judges to the courts of appeals, including Judge Janice Rogers Brown, a controversial nominee who was involved in a Senate filibuster (Babington 2005). Future studies that include these new female minority judges are needed to support and reevaluate theories concerning dual outgroup status. Additionally, our findings demonstrate the importance of group identification under certain, but by no means all, conditions. Here, criminal justice appears to be an issue area that is salient in terms of both the race and gender of judges. Further research should explore the extent to which this cohesion among minority females exists in other types of cases brought before the courts of appeals and other judicial settings.

Furthermore, this study suggests that researchers should continue to examine the effects of overlapping characteristics rather than certain characteristics singularly. Our findings suggest the need to focus more upon the overlap of many different characteristics to understand the importance of a judge's background and experiences upon the decisions they make. For example, being raised in a family of low wealth, alone, may appear to have little impact on a judge's decisions. However, the overlap of prior wealth and other characteristics, such as race, gender, or other personal traits, may indeed influence judges and other political elites' behaviors. While the findings in this study are important in understanding judicial behaviors, they also raise theoretical implications for studying the actions of those political elites outside of the courtroom. As scholars continue to refine their measures of personal characteristics and examine new ways of explaining behaviors, the intersectionality of personal traits should be an important factor for exploration into political actors' decisions and behavior.

\section{Notes}

1. For the purposes of this analysis, "minority" refers to African American, Hispanic, or Asian individuals; and "Caucasian" refers to individuals who are Caucasian white.

2. The Multi-User Database on the U.S. Courts of Appeals contains published appellate opinions from 1925 to 1996 and is available at http://www.as.uky.edu/polisci/ulmerproject/appctdata.htm. The updated database is funded by the National Science Foundation (SES-0318349 and is available at http://www.wmich .edu/nsf-coa/.

3. The judge attribute database can by found at the S. Sidney Ulmer Project at the University of Kentucky, http://www.as.uky .edu/polisci/ulmerproject/appctdata.htm.

4. The lack of independence between observations is accounted for by specifying the Huber/White/sandwich estimator (Huber 1967; Rogers 1993; White 1980). Base terms will include cases decided in years 1982 to 1993 and the D.C. Circuit.

5. Cohort analysis was selected over interaction terms because the former allows for comparisons between groups, rather than comparing minority-female judges to all other judges. An interactive model (not shown) was also conducted, and the interaction of gender and race was statistically significant, indicating that minority females are more likely to support liberal outcomes than all other groups, collectively. However, the cohort analysis allows conclusions to be drawn as to whether minority-female judges were more likely to support liberal outcomes than each group, individually.

6 . The $p$-value for the minority-judge variable in the second column in Table 2 was .495 . The $p$-value for the gender variable 
in the third column of Table 2 was .924 , suggesting that neither variable was statistically significant at generally acceptable confidence levels.

7. A model assessing the joint effects, utilizing an interactive variable (Norton, Wang, and Ai 2004), was also conducted. The interactive effects (not shown) of being a female and a minority have a statistically significant and positive influence on judicial voting, indicating that minority female judges have a higher likelihood of supporting the defendant's position, even after controlling for the other independent variables.

8. While most of these were Clinton appointees, a separate analysis (not shown) indicates that even within the Clinton appointees, female-minority judges were statistically more likely to support the defendant's position than were other Clinton appointees overall.

\section{References}

Allen, David W., and Diane E. Wall. 1993. Role orientations and women state supreme court justices. Judicature 77:156-65.

Babington, Charles. 2005. Republicans refuse offer over judges. Washington Post, April 27, A:21.

Blalock, Hubert M. 1979. Social statistics. New York: McGraw-Hill.

Bratton, Kathleen A., and Kerry L. Haynie. 1999. Agenda setting and legislative success in state legislatures: The effect of gender and race. Journal of Politics 61 (3): 658-79.

Browning, Sandra Lee, and Linqun Cao. 1992. The impact of race on criminal justice ideology. Justice Quarterly 9:685-99.

Cao, Linqun, and James Franks. 1996. Race, community contest, and confidence in the police. American Journal of Police 15:3-22.

Crenshaw, Kimberle. 1989. Gender, race, and the politics of Supreme Court appointments: The import of the Anita Hill/Clarence Thomas hearings: Race, gender, and sexual harassment. University of Chicago Legal Forum, March, pp. 139-67.

- 1992. Race, gender, and sexual harassment. Southern California Law Review 65:1467-76.

Cross, Frank, and Emerson Tiller. 1998. Judicial partisanship and obedience to legal doctrine: Whistleblowing on the federal courts of appeals. Yale Law Journal 107 (7): 2155-76.

Curran, Barbara. 1977. The legal needs of the public: The final report of a national survey. Chicago: American Bar Association.

Davis, Sue. 1991. Do women judges speak in a different voice? Carol Gilligan, feminist legal theory, and the Ninth Circuit. Wisconsin Women's Law Journal 8:143.

Dolan, Kathleen, and L. E. Ford. 1995. Women in the state legislatures: Feminist identity and legislative behaviors. American Politics Quarterly 23:96.

Easton D., and J. Dennis. 1969. Children in the political system: Origins of political legitimacy. New York: McGraw-Hill.

Federal Judicial Center. n.d. History of the federal judiciary. http://www.fjc.gov/history/home.nsf (accessed June 5, 2007).

Giles, Michael W., Virginia A. Hettinger, and Todd Peppers. 2001. Picking federal judges: A note on policy and partisan selection agendas. Political Research Quarterly 54:623-41.

Gilligan, Carol. 1982. In a different voice: Psychological theory and women's development. Cambridge, MA: Harvard University Press.

Goldman, Sheldon. 1997. Picking federal judges-Lower court selection from Roosevelt through Reagan. New Haven, CT: Yale University Press.
Gottschall, Jon. 1983. Carter's judicial appointments: The influence of affirmative action and merit selection on voting on the U.S. courts of appeals. Judicature 67:165-73.

Gruhl, John, Casia Spohn, and Susan Welch. 1981. Women as policymakers: The case of trial judges. American Journal of Political Science 25:308-22.

Hagan, John, and Celesta Albonetti. 1982. Race, class, and the perception of criminal injustice in America. American Journal of Sociology 88:329-55.

Hancock, Ange-Marie. 2007. When multiplication doesn't equal quick addition: Examining intersectionality as a research paradigm. Perspectives on Politics 5 (1): 63-79.

Harris, Angela P. 1990. Race and essentialism in feminist legal theory. Stanford Law Review 42:581-615.

Hettinger, Virginia A., Stefanie A. Lindquist, and Wendy L. Martinek. 2004. Comparing attitudinal and strategic accounts of dissenting behavior on the U.S. courts of appeals. American Journal of Political Science 48 (1): 123-37.

- 2006. Judging on a collegial court-Influences on federal appellate decision making. Charlottesville: University of Virginia Press.

Huber, P. J. 1967. The behavior of maximum likelihood estimates under nonstandard conditions. In Proceedings of the Fifth Berkeley Symposium on Mathematical Statistics and Probability, 221-23. Berkeley: University of California Press.

Kane, Emily W. 1992. Race, gender, and attitudes toward gender stratification. Social Psychology Quarterly 55 (3): 311-20.

Keiser, Lael, Vicky M. Wilkins, Kenneth J. Meier, and Catherine A. Holland. 2002. Lipstick and logarithms: Gender, institutional context, and representative bureaucracy. American Political Science Review 96:553-64.

Kennedy, Randall. 1997. Race, crime, and the law. New York: Pantheon Books.

Liao, Tim Futing. 1994. Interpreting probability models. Thousand Oaks, CA: Sage.

Long, J. Scott, and Jeremy Freese. 2003. Regression models for categorical dependent variables using Stata. College Station, TX: Stata Corporation.

Manning, Kenneth A., Bruce L. Carroll, and Robert A. Carp. 2004. Does age matter? Judicial decision making in age discrimination cases. Social Science Quarterly 85 (1): 1-18.

Martin, Susan E. 1994. "Outsider within" the station house: The impact of race and gender on black women police. Social Problems 41 (3): 383-400.

Miller, Cheryl M. 1990. Agenda setting by state legislative black caucuses: Policy priorities and factors of success. Policy Studies Review 9 (2): 339-54.

Miller, J. L., Peter H. Rossi, and Jon E. Simpson. 1986. Perceptions of justice: Race and gender differences in judgments of appropriate prison sentences. Law and Society Review 20 (3): 313-34.

Myer, Laura B. 1996. Bringing the offender to heel: Views of the criminal courts. In Americans view crime and justice: A national public opinion survey, ed. Timothy J. Flanagan and Dennis R. Longmire. Newbury Park, CA: Sage.

National Center for State Courts. 1999. How the public views the state courts: A 1999 national survey. Presented at the National Conference on Public Trust and Confidence in the Justice System, May 14, 1999, Washington, DC. http:// ppc.unl.edu/publications/ documents/how_public_views_the_state_courts.pdf.

Norrander, Barbara. 2003. The intraparty gender gap: Differences between male and female voters in the 1980 to 2000 presidential primaries. PS: Political Science and Politics 36:181-86. 
Norton, Edward C., Hua Wang, and Chunrong Ai. 2004. Computing interaction effects and standard errors in logit and probit models. Stata Journal 4:154-67.

Peresie, Jennifer L. 2005. Female judges matter: Gender and collegial decision-making in the federal appellate courts. Yale Law Journal 114:1759-90.

Pierce, J. C., K. Beatty, and P. R. Hagner. 1982. The dynamics of american public opinion. Glenview, IL: Scott, Foresman.

Prestage, Jewel L. 1991. In quest of African American political woman. Annals of the American Academy of Political and Social Science 515:88-103.

Rogers, W. H. 1993. Regression standard errors in clustered samples. Stata Technical Bulletin. 3:sg17.

Scherer, Nancy. 2004-2005. Blacks on the bench. Political Science Quarterly 119 (4): 655-75.

Schlozman, Kay Lehman, Nancy Burns, and Sidney Verba. 1994. Gender and the pathways to participation: The role of resources. Journal of Politics 56:963-90.

Schubert, Glendon. 1965. The judicial mind: Attitudes and ideologies of Supreme Court justices, 1946-1963. Evanston, IL: Northwestern University Press.

Segal, Jeffrey A. 1986. Supreme Court justices as human decision makers: An individual-level analysis of search and seizure cases. Journal of Politics 67:938-55.

Segal, Jeffrey A., Richard J. Timpone, and Robert M. Howard. 2000. Buyer beware? Presidential success through Supreme Court appointments. Political Research Quarterly 3:557-95.

Segal, Jennifer. 2000. Representative decision making on the federal bench: Clinton's district court appointees. Political Research Quarterly 53:137-50.

Songer, Donald R. 1982. Consensual and nonconsensual decisions in unanimous opinions of the United States courts of appeals. American Journal of Political Science 26 (2): 225-39. . 1997. The United States courts of appeals database. Ann Arbor, MI: Inter-university Consortium for Political and Social Research. http://www.as.uky.edu/polisci/ulmerproject/ appctdata.htm.
Songer, Donald, and Sue Davis. 1990. The impact of party and region on voting decisions in the U.S. courts of appeals, 195586. Western Political Quarterly 43:317-86.

Songer, Donald, Sue Davis, and Susan Haire. 1994. A reappraisal of diversification in the federal courts: Gender effects in the courts of appeals. Journal of Politics 56:425-39.

Songer, Donald, and Susan Haire. 1992. Integrating alternative approaches to the study of judicial voting: Obscenity cases in the U.S. courts of appeals. American Journal of Political Science 36 (4): 963-82.

Songer, Donald R., Jeffrey A. Segal, and Charles M. Cameron. 1994. The hierarchy of justice: Testing a principle-agent model of Supreme Court-circuit court interactions. American Journal of Political Science 38:673-96.

Songer, Donald, and Reginald Sheehan. 1992. Who wins on appeal? Upperdogs and underdogs in the United States courts of appeals. American Journal of Political Science 36:235-68.

Swers, Michelle. 2002. The difference women make: The policy impact of women in Congress. Chicago: University of Chicago Press.

Walker, Thomas G., and Deborah J. Barrow. 1985. The diversification of the federal bench: Policy and process ramifications. Journal of Politics 47 (2): 596-617.

Welch, Susan, Michael Combs, and John Gruhl. 1998. Do black judges make a difference? American Journal of Political Science 32:126-36.

White, H. 1980. A heteroskedasticity-consistent covariance matrix estimator and a direct test for heteroskedasticity. Econometrica 48:817-30.

Whitford, Andrew, and Jeff Yates. 2003. Policy signals and executive governance: Presidential rhetoric in the war on drugs. Journal of Politics 65:995-1012.

Zuk, Gary, Deborah J. Barrow, and Gerard S. Gryski. 1997. Multi-user database on the attributes of United States appeals courts judges, 1801-1994. Ann Arbor, MI: Inter-university Consortium for Political and Social Research. 